\title{
KINETICS OF THE NATURAL EVOLUTION OF HYDROGEN CYANIDE IN PLANTS IN NEOTROPICAL Pteridium arachnoideum AND ITS ECOLOGICAL SIGNIFICANCE
}

\author{
MIGUEL E. ALONSO-AMELOT ${ }^{1, *}$ and ALBERTO OLIVEROS-BASTIDAS ${ }^{1}$ \\ ${ }^{1}$ Departamento de Química, Facultad de Ciencias \\ Grupo de Química Ecológica \\ Universidad de Los Andes \\ Mérida 5101, Venezuela
}

(Received July 30, 2003; accepted October 20, 2004)

\begin{abstract}
The time-dependent natural release of hydrogen cyanide ( $\mathrm{HCN})$ was studied quantitatively using young croziers of the neotropical bracken fern Pteridium arachnoideum. HCN production was quantified in crushed tissue using a flow reactor at $30.0 \pm 0.1{ }^{\circ} \mathrm{C}$. Released $\mathrm{HCN}$ was carried into appropriate traps with a moist air flow. Aliquots were drawn from the traps at fixed time intervals, and the $\mathrm{HCN}$ concentration was evaluated spectroscopically. All available prunasin (Pru), the only cyanogenic glycoside present, underwent decomposition into HCN in less than 1200 min. Fiddleheads $(N=76)$ contained 1.84-107.70 $\mathrm{mg} \mathrm{Pru} \mathrm{g}^{-1} \mathrm{dw}$ in a continuous fashion suggesting genetic polymorphism. Acyanogenic morphs were rare (1/77). From the kinetics of the samples with Pru content near the median histographic distribution $(N=46)$, accumulated $\mathrm{HCN}$ formation as a function of time, initial velocities, average $\mathrm{HCN}$ production rate, and corresponding rate equations were obtained. Initial and average velocities correlated well with total Pru content. The yield of cyanide liberation varied widely between 0.51 and $47.86 \mu \mathrm{g} \mathrm{HCN} \mathrm{min}^{-1} \mathrm{~g}^{-1}$ $\mathrm{dw}$ and was a linear function of $[\mathrm{Pru}]_{t}$. However, the $\beta$-glucosidase enzyme involved in this reaction was not rate limiting and occurs in excess in the natural system. Enzyme activity was found to be independent of $[\mathrm{Pru}]_{t}$. The contribution of $\mathrm{HCN}$ as an allomone-upon-request against herbivores was assessed quantitatively. Bracken fiddleheads produced a pulse of $\mathrm{HCN}$ soon after tissue injury that waned rapidly, leaving a large portion of intact prunasin to decompose more slowly in the herbivore's lumen. The balance between the external
\end{abstract}

\footnotetext{
* To whom correspondence should be addressed. E-mail: alonso@ula.ve
} 
and internal courses was found to depend on the concentration of prunasin in the plant, the amount of crozier eaten, and the time used to consume it.

Key Words-Cyanogenesis, kinetics, defense, herbivory, Pteridium arachnoideum.

Abbreviations: $[\mathrm{Pru}]_{t}$, Total prunasin contained in a given sample; $v_{\mathrm{A}}$, Average velocity of $\mathrm{HCN}$ formation; $v_{\mathrm{R}}$, Average velocity of $\mathrm{HCN}$ evolution relative to $[\mathrm{Pru}]_{t}$ in the sample; $v_{\mathrm{i}}$, Initial velocity of $\mathrm{HCN}$ formation during the first few minutes after tissue crushing; $\Re$, The time-dependent accumulated formation of $\mathrm{HCN} \mathrm{g}^{-1} \mathrm{dw}$ of crozier relative to $[\mathrm{Pru}]_{t} ; \Delta v_{\mathrm{A}} / \Delta \tau$, Time-dependent variation in the velocity of $\mathrm{HCN}$ evolution.

\section{INTRODUCTION}

Cyanogenesis, or the emanation of hydrogen cyanide (HCN), has long been recognized as an effective means of deterring predation (Ellis et al., 1977; Conn, 1981; Nahrstedt, 1988; Schappert and Shore, 1999a; Magalhaes et al., 2000). Plants, in particular, are capable of yielding HCN (Jones, 1998; Vetter, 2000) when their tissues are crushed during maceration by chewing herbivores (Vetter, 2000). In some tropical environments where insect pressure is high, as many as $4 \%$ of woody plants are cyanogenic and concentrate $\mathrm{HCN}$ precursors in reproductive parts (Thomsen and Brimer, 1997).

Since HCN is not only toxic to many animals, but also deleterious to the producing organism, it is generally stored as a stable precursor or phytoanticipin, glycosylated $\alpha$-cyanohydrins of which many are known. Under the operation of an appropriate $\beta$-glucosidase, the glycoside portion can be excised. The cyanohydrin, which may itself be implicated in xenobiosis (Magalhaes et al., 2000), either decomposes on standing by way of $\beta$-elimination or under the auspices of a second enzyme, a hydroxynitrile lyase. Both routes yield HCN and a carbonyl component, generally an aldehyde or ketone that may have deterrent functions of its own (Peterson et al., 1987).

Gaseous HCN so produced is likely to be involved in trophic interactions (Jones, 1973; Jones et al., 1978; Conn, 1979). Thus, during feeding, HCN escapes into the atmosphere immediately surrounding the producer. However, for HCN to be an effective deterrent, a sufficiently high concentration of the gas must be attained (Nahrstedt, 1985; Jones, 1998). To achieve this goal, and in attention to the natural diffusion of this gas in air and its dispersion by wind, two ingredients must participate from the producer standpoint: the amount of $\mathrm{HCN}$ precursors available and the rate at which the cyanogenic glycoside-enzyme system is capable of releasing $\mathrm{HCN}$.

Much attention has been paid to the first of these factors (e.g., Conn, 1981; Seigler, 1998; Gleadow and Woodrow, 2002; Goodger et al., 2002), in terms of 
frequency of cyanogenic genotypes, actual content of cyanogenic glycosides in tissues at risk, and impact on associated biota (Zagrobelny et al., 2004). A great deal of variability has been observed. For example, cyanogenic species such as Trifolium repens contain enough cyanogenic glycosides to give between 3.2 and $350 \mu \mathrm{g}$ of $\mathrm{HCN} \mathrm{g}^{-1} \mathrm{dw}$, while others like Linum usitatisimum and Dimorphoteca ecklonis are capable of yielding a total of 910 and $1580 \mu \mathrm{g}$ of $\mathrm{HCN}$, respectively (Butler, 1965). The seasonal variability in cyanogenic glycoside content has also been recognized (Cooper-Driver et al., 1977; Gleadow and Woodrow, 2000; Gebrehiwot and Beuselinck, 2001). However, the amount of cyanogenic glycosides alone and their static potential to yield $\mathrm{HCN}$ have not satisfied all questions open to cyanogenesis as an effective defense strategy (Hruska, 1988; Gleadow and Woodrow, 2002).

With regard to the second component, the kinetics of the natural $\mathrm{HCN}$ gas formation from crushed plant tissue has rarely been investigated in cyanogenic plants. One recent report (Goodger et al., 2002) records the initial velocity of HCN release from foliage of cyanogenic genotypes of Eucalyptus polyanthemos in Southern Australia between 0.02 and $0.14 \mu \mathrm{g} \mathrm{g}^{-1} \mathrm{dw} \mathrm{hr}{ }^{-1}$. This is the result of the rate of the combined reactions leading to the formation of HCN. In a first approximation, we had estimated the pseudo first-order rate of prunasin decomposition in Pteridium aquilinum (L.) Kuhn as $2.20 \pm 0.01 \times 10^{-4} \mathrm{sec}^{-1}$ (Alonso-Amelot and Oliveros, 2000). Earlier, the kinetics of the enzymatic transformation of the mandelonitrile was examined in vitro using Hevea brasiliensis enzymes (Jorns, 1980; Bauer et al., 1999). Both reaction products, HCN and benzaldehyde, were found to act as substrate competitors against mandelonitrile to inhibit the enzyme, indicating a degree of product self-regulation. These advances provide thrust to develop kinetic data of natural cyanogenesis in plants that might help to understand the ecological significance of this defense line and the toxic potential to animals and humans.

One of the cyanogenic plants in which a clear selection against the cyanogenic genotypes by vertebrates has been recognized is $P$. aquilinum (Cooper-Driver et al., 1977; Hadfield and Dyer, 1986; Low and Thomson, 1990). Few insects use this abundant resource as feed (Lawton, 1976; Jones, 1983; Salinas and Ortega, 1990). Cyanogenesis stemming from its only precursor, prunasin (Kofod and Eyjolfsson, 1966; Berti and Bottari, 1968), among other lines of chemical defense (AlonsoAmelot, 2002), is thought to be in part responsible (Schreiner et al., 1984).

Therefore, bracken fern stood as well-suited for examining its cyanogenic potential in terms of the rate at which $\mathrm{HCN}$ is produced upon crushing, in light of the hypothesis regarding its ecological role. Among the Pteridium taxon, the species P. arachnoideum (Kaulf.) Maxon (Pteridophyta: Dennstaedtiaceae) was selected because of its abundance and success in mountainous regions of the neotropics (Ortega, 1990) where (year round) pressure by herbivory is high and there is a high frequency of cyanogenic morphs (99\%, personal observation). Thus, 
the time-dependent evolution of gaseous $\mathrm{HCN}$ from this plant, the initial velocity of its formation, its correlation with the amount of prunasin present, the variation of the reaction rate with time, and the rate dependence on total prunasin content were investigated in the young bracken crozier. No efforts to derive a molecular mechanistic elucidation were attempted, and the results are only interpreted within the ecological context.

\section{METHODS AND MATERIALS}

Warning. Solid picric acid and sodium picrate may explode spontaneously when stored for long periods. It is advisable to maintain this material always as a supersaturated water solution or suspension at temperatures not exceeding $20^{\circ} \mathrm{C}$ and avoid all contact with skin to prevent long-term toxic effects. Sodium cyanide is highly toxic and should never be handled as solid, in neutral or acidic solutions without proper protection or outside a fume hood.

Reagents and Apparatus. Sodium bicarbonate (J. T. Baker Chemical Co.) and picric acid (BDH Laboratory Reagents) were used without further purification. Sodium cyanide was purified by recrystallization from ethanol-dichloromethane solutions and dissolved in degassed water. Almond emulsin (Sigma-Aldrich, Milwaukee, Wisconsin) was used as source of $\beta$-glucosidase. Absorbances of sodium picrate-cyanide complex were determined at $515 \mathrm{~nm}$ using an HewlettPackard (Palo Alto, California) Vectra UV-Vis 8453 spectrophotometer controlled by a Vectra-Pentium I workstation. Field temperature measurements were determined from mid-April to mid-May of 1999 and 2002 at sites A and B with the aid of StowAway XTI field logs (Onset Computer Corp., Bourne, Massachussetts).

Plant Sampling. P. arachoideum grows in dense thickets in open areas affected by fire or cattle husbandry, and in natural grasslands in the Andes mountain range of western Venezuela. Plants can persist for many years without further human intervention (Alonso-Amelot and Rodulfo, 1996). Voucher specimens were collected and stored in the laboratory herbarium, and also sent to the New South Wales Botanical Gardens in Sydney, Australia (NSW 361276). Four sites for the survey of cyanogenic morphs were selected in the 1880-2100 $\mathrm{m}$ altitudinal range. All sites were located between $8^{\circ} 30^{\prime}$ to $8^{\circ} 42^{\prime} \mathrm{N}$ and $71^{\circ} 04^{\prime}$ and $71^{\circ} 19^{\prime} \mathrm{W}$ in the environs of the city of Mérida, Venezuela and surrounding mountains. Sampling was performed at the onset of the rainy season, between late March and May of 2003. At each site, 25-35 croziers of $P$. arachnoideum (30-40 cm long) were cut at ground level, stored in plastic clip bags, and brought to the laboratory within $2 \mathrm{hr}$. Ten of the collected croziers were analyzed for moisture content, and the remaining were used for chemical analysis. As it was determined that the crozier apex contained the greater amount of prunasin, only this part was used for the kinetic measurements. 
Temperature Determination of Kinetics Runs. To emulate in the laboratory the thermal conditions where cyanogenesis of croziers takes place naturally in the field, it was necessary to determine the temperature at which bracken stands grow in our geographical area. An average temperature of $29.9^{\circ} \mathrm{C}$ during the hours of maximum insect activity (10 A.M.-5 P.M.) was recorded within the bracken canopy during the April-May period with the aid of field logs. Therefore, the kinetic runs were standardized at $30.0 \pm 0.1^{\circ} \mathrm{C}$.

HCN Analysis. The sodium picrate gas flow quantitation method of AlonsoAmelot and Oliveros (2000) was employed as it provided the selective detection of $\mathrm{HCN}$ through its picrate complex at $\lambda=515 \mathrm{~nm}$ without interference from other carbonyl volatiles possibly stemming from the plant sample. Indeed, an acyanogenic morph of bracken yielded no response in the picrate absorption spectrum between 480 and $700 \mathrm{~nm}$, confirming the lack of interfering components not associated with the process of cyanogenesis. Benzaldehyde and other carbonyl compounds were trapped in the first dinitrophenyl hydrazine solution through which the gas flow was passed (see below). A known amount (0.6-1.2 g) of intact, fresh bracken crozier heads were crushed with mortar and pestle using acid-washed sand $(3-5 \mathrm{~g})$ as abrasive $\left(-15^{\circ} \mathrm{C}\right.$ for $\left.3 \mathrm{~min}\right)$. The cold mass was rapidly placed into a $12 \mathrm{ml}$ flow reactor constructed from a disposable plastic syringe. The syringe was inserted into the gas-flow system and immersed into a circulating water bath at $30 \pm 0.1^{\circ} \mathrm{C}$ at time zero when the gas flow was started. The gas flow was conducted through a first trap of dinitrophenyl hydrazine in acidic water-ethanol solution as previously described, and then through a saturated alkaline picrate solution $(10.0 \mathrm{ml})$ where all $\mathrm{HCN}$ was trapped. With the aid of a precision syringe, a $1.0 \mathrm{ml}$ aliquot was drawn every $20 \mathrm{~min}$ for $180 \mathrm{~min}$, and then every $60 \mathrm{~min}$. One last measurement was performed after $1200 \mathrm{~min}(20 \mathrm{hr})$ when no additional HCN evolution occurred. Immediately after every aliquot was drawn, $1.0 \mathrm{ml}$ of fresh picrate solution was added to the gas trap. Therefore, the corresponding dilution factor was applied to calculate the actual amount of $\mathrm{HCN}$ incorporated into the picrate solution in every time interval, using the following equation

$$
[\mathrm{HCN}]_{i}=[\mathrm{HCN}]_{m(i)}-0.81 \times[\mathrm{HCN}]_{(i-1)}
$$

where

\begin{tabular}{|c|c|c|}
\hline $\mathrm{ICN}$ & & \\
\hline $\mathrm{HCN}$ & & $\begin{array}{l}\text { HCN concentration during the previous } \\
\text { d }\end{array}$ \\
\hline & & $\begin{array}{l}\text { spectrally measured HCN concentration in each aliquot } \\
\text { corresponding to the } i \text { th time period }\end{array}$ \\
\hline
\end{tabular}

The dilution factor (0.81) was derived from the combination of the remaining $\mathrm{HCN}$ in the picrate when an aliquot $(1.0 \mathrm{ml})$ was drawn and the $9 \mathrm{ml}$ remaining 
solution was brought back to $10.0 \mathrm{ml}$ by the addition of fresh picrate $(1.0 \mathrm{ml})$. $[\mathrm{HCN}]_{m(i)}$ was determined by contrasting the spectral absorbance at $515 \mathrm{~nm}$ of the $\mathrm{HCN}-$ picrate complex against a calibration regression $\left(r^{2}=0.99, P<10^{-4}\right)$ of $\mathrm{NaCN}$ solutions in the standard basic picrate reagent (range: $2.0-200.0 \mu \mathrm{g} \mathrm{HCN}$ equivalents).

All samples were allowed to stand in the gas flow reactor for a total of $20 \mathrm{hr}$, to ensure that all the prunasin was decomposed into HCN. To confirm that the measured $\mathrm{HCN}$ represented the total content of prunasin, a phosphate buffered $(\mathrm{pH}=6.8) \beta$-glucosidase solution $(0.2 \% \mathrm{w} / \mathrm{v})$ was added to the moist sandcrushed crozier mass in the flow reactor after the end of the kinetics experiment. The passing gas was examined for the presence of $\mathrm{HCN}$. No additional hydrocyanic acid could be detected. Therefore, Eq. (2) conveyed the total amount of prunasin present.

$$
[\mathrm{HCN}]_{(1200 \mathrm{~min})} \times\left[\frac{\mathrm{MW}(p)}{\mathrm{MW}(\mathrm{HCN})}\right]=[\text { Prunasin }]_{t}
$$

Here MW is the molecular weight of species. A total of 76 croziers were studied kinetically.

Isolation of Prunasin. Modification of the method suggested by Brinker and Seigler (1992) was used. Freshly collected crozier heads (314 g) were dried under high vacuum ( $72 \mathrm{hr}$ ) yielding $43.5 \mathrm{~g}$ of material that was blended to a fine powder. This material was extracted in boiling methanol-water $4: 1(800 \mathrm{ml} \times 2)$ to counteract possible enzymatic decomposition of the cyanogenic glucoside. Each batch was then placed into an ultrasound bath for $30 \mathrm{~min}$ at $35^{\circ} \mathrm{C}$. A $5 \%$ solution of lead acetate was added to the filtrate at room temperature to precipitate tannin and pigments. After filtration and centrifugation of solids, methanol in the supernatant was removed by rotary evaporation below $35^{\circ} \mathrm{C}$. The remaining aqueous solution was frozen and freeze dried to a light yellowish powder (4.6 g) This material was purified by flash column chromatography using TLC-grade silica gel. Fractionation was conveniently monitored by $\beta$-glucosidase treatment of each fraction $(5 \mu \mathrm{l})$ after solvent exchange to water at $\mathrm{pH}=5.5$, Sep-Pack (Millipore) pre-purification and HPLC determination of the formation of benzaldehyde (reverse-phase $\mathrm{C}_{18}$, $10 \mathrm{~cm}$ Radial Pack column, $\mathrm{MeOH}-\mathrm{H}_{2} \mathrm{O}$ 70:30, $1 \mathrm{ml} \mathrm{min}^{-1}, 6.06 \mathrm{~min}$ ret. time, $\lambda_{\max }=210$ and $245 \mathrm{~nm}$ ). This method requires only very small amounts of $\beta$ glucosidase and is more specific than the sodium picrate paper-TLC sandwich procedure (Brimer et al., 1983). The fraction eluting with ethyl acetate-acetonemethanol-water 16:3:2:2 gave the only HCN-yielding component. This fraction was further purified by thick layer chromatography (same solvent mixture, 8:1:1:1, $\left.R_{\mathrm{f}}=0.3-0.45\right)$ and crystallization from methanol-dichloromethane-hexane mixtures $\left(187 \mathrm{mg}, \mathrm{mp}=146-148^{\circ} \mathrm{C}\right)$.

Comparison of Enzyme Activity. Twelve field collected samples from the same sites above, each consisting of seven bracken fiddleheads were vacuum-dried, 
reduced to a fine powder, and stored at $-15^{\circ} \mathrm{C}$ until use. Each sample was subdivided in two subsamples. The kinetics of natural decomposition of prunasin to $\mathrm{HCN}$ in the first subsample $(0.400 \mathrm{~g} \mathrm{dw})$ was determined as above except that, at the time of cold sand maceration, the original water content was reconstituted ( $1.6 \mathrm{ml}$ corresponding to $80 \%$ moisture content). After $1200 \mathrm{~min}$, the total amount of HCN collected in the picrate trap gave the prunasin content of the sample. At the time of cold sand maceration, to each one of the second subset of samples was added enough purified prunasin [as a cold $\left(2^{\circ} \mathrm{C}\right)$ water solution, 16-231 $\mu$, plus enough distilled water to complete $1.6 \mathrm{ml}$ ) to give a final concentration of $12.0 \mathrm{mg} \mathrm{g}^{-1} \mathrm{dw}$ of the cyanogenic glucoside. The kinetics was then determined as above. In both sets, the initial velocities were calculated from the first degree coefficient of the $2^{\circ}$ polynome to which the plot of accumulated $\mathrm{HCN} \mathrm{g}^{-1} \mathrm{dw}$ vs. time, up to $180 \mathrm{~min}$, was best adjusted $\left(r^{2}>0.997\right)$.

In a second series of experiments, the exact weight $\left( \pm 10^{-4} \mathrm{~g}\right)$ of approx. $0.35 \mathrm{~g}$ of fresh crozier head was determined, and the remaining material was used to estimate its dry weight. The sample was crushed with $10 \mathrm{~g}$ of fine sand at $-15^{\circ} \mathrm{C}$ for $1 \mathrm{~min}$ adding $500 \mu \mathrm{l}$ of phosphate buffer $\mathrm{pH} 6.8$. The mixture was quickly placed inside the flow reactor, warmed to $30.0 \pm 0.1^{\circ} \mathrm{C}$ and the kinetics of $\mathrm{HCN}$ evolution determined during the first $180 \mathrm{~min}$ as described. A second sample excised from the same bracken plant was processed similarly except that $500 \mu \mathrm{l}$ of $\beta$-glucosidase solution in phosphate buffer $\mathrm{pH} 6.8$ was added during maceration. The enzyme solution was prepared from $1.0 \mathrm{mg}$ of commercial almond emulsin dissolved in $1.0 \mathrm{ml}$ of phosphate buffer, from which $50 \mu \mathrm{l}$ was drawn and dissolved in $450 \mu \mathrm{l}$ of buffer. The kinetics of HCN evolution was determined as before.

Statistical Calculations. Data were analyzed with Kruskal-Wallis and ANOVA tests of comparison of the means were performed using Statistix V 7.0 package (Analytical Software, St. Paul, MN). Curve fitting, plotting, and accompanying statistics were accomplished with Origin Professional software package V 5.0 (Microcal Software, Northampton, MA).

\section{RESULTS}

P. arachnoideum Cyanogenic Potential. The crozier phenological stage of bracken was selected as the best sample, because it contained the largest concentration of prunasin (Lawton, 1976). It was also the more fragile phase, with softer tissues, only one irreplaceable meristem, and close to ground-bound plant predators.

Table 1 shows the results of a homogeneity test for prunasin content of the four field populations. There were no statistically significant differences between the means (ANOVA within differences: $F=3.28, P=0.037$ ). Prunasin content ranged from 1.84 to $107.70 \mathrm{mg} \mathrm{Pru} \mathrm{g}^{-1} \mathrm{dw}$ (mean $=18.62 \pm 20.82 \mathrm{mg} \mathrm{Pru} \mathrm{g}^{-1} \mathrm{dw}$ ) in a continuous fashion (Figure 1A) with $70 \%$ of the samples containing between 
TABle 1. Comparison of PRUNASin CONTENT $\left(\mu \mathrm{g} \mathrm{g}^{-1} \mathrm{dw}\right)$ IN CROZIERS OF Four Allopatric POPULATIONS OF NEOTROPICAL

Pteridium arachnoideum $(N=46)$

\begin{tabular}{lcccl}
\hline Population & A & B & C & \multicolumn{1}{c}{ D } \\
\hline Mean & 21,661 & 11,596 & 31,687 & 23,614 \\
SE & $3,200.1$ & $1,524.5$ & $8,859.8$ & $64,221.8$ \\
Minimum & $7,613.2$ & $4,725.0$ & $12,827.2$ & $24,20.1$ \\
Maximum & $33,948.8$ & $15,886.1$ & $64,239.3$ & $64,133.1$ \\
\hline
\end{tabular}

2 and $39 \mathrm{mg} \mathrm{Pru} \mathrm{g}^{-1} \mathrm{dw}$ (Figure 1B). Of the 77 samples collected, only one was acyanogenic. Efforts to find other acyanogenic genets among $P$. arachnoideum in the typical bracken grounds in the fields near Mérida failed. Squeezing young crozier heads between the fingers released enough benzaldehyde- the co-product of prunasin decomposition - to be clearly noticeable by smell, a quality that allowed for the fast identification of strongly cyanogenic populations of bracken in the field.

Kinetics of Cyanogenesis. In the kinetic runs of crushed croziers, the average rate of $\mathrm{HCN}$ formation $v_{\mathrm{A}}\left(\mu \mathrm{g} \mathrm{HCN} \min ^{-1}\right)$ was calculated from the increments per 20-min period of the evolution of HCN during the first 180 min of incubation at $30.0 \pm 0.1^{\circ} \mathrm{C} . v_{\mathrm{A}}$ of each independent sample was a linear function of

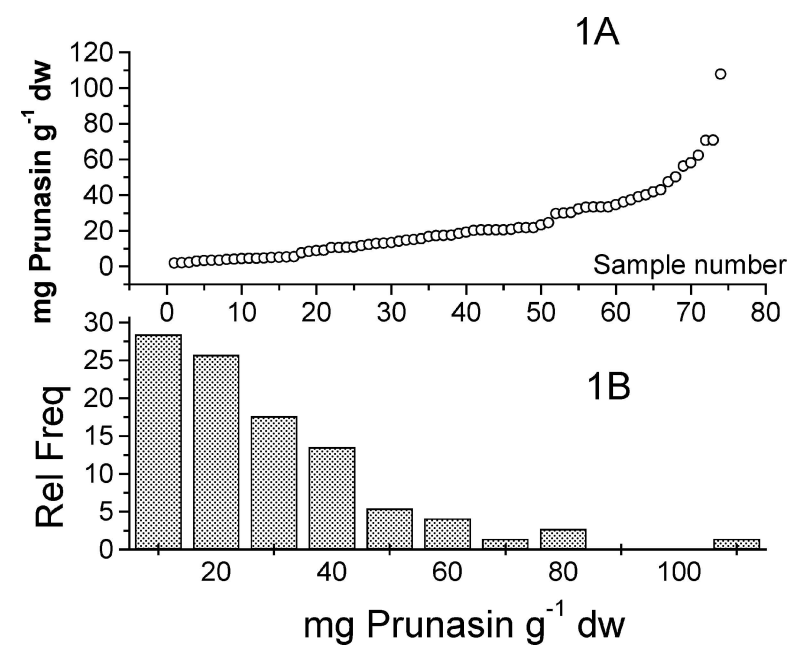

FIG. 1. Concentrations of prunasin in $P$. arachnoideum crozier head samples used in this study (A) $(N=74)$ and histogram of prunasin distribution in $10 \mathrm{mg} \mathrm{g}^{-1} \mathrm{dw}$ intervals (B). 


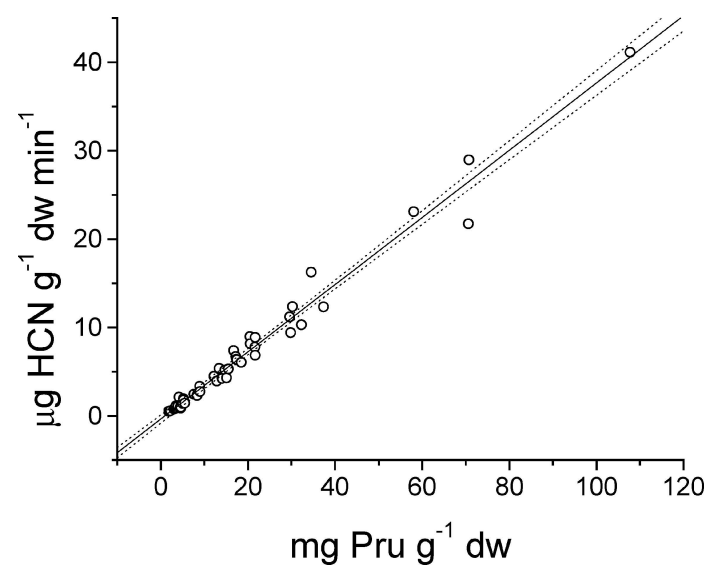

FIG. 2. Correlation between the increment of $\mathrm{HCN}$ production per unit time $v_{A}\left(\mu \mathrm{g} \mathrm{g}^{-1}\right.$ $\left.\mathrm{dw} \mathrm{min}^{-1}\right)$ and the total prunasin (Pru) $\left(\mathrm{mg} \mathrm{g}^{-1} \mathrm{dw}\right)$ contained in the crozier head. The linear regression followed the expression: $\mathrm{HCN}\left[\mu \mathrm{g} \mathrm{g}^{-1} \mathrm{dw} \min ^{-1}=-0.36( \pm 0.23)+\right.$ $\left.0.38( \pm 0.008) \times[\mathrm{Pru}]_{t} . N=48, r=0.989, S D=1.180, P<0.001\right]$. Dotted lines denote the $95 \%$ confidence limits of the regression.

the total prunasin $[\mathrm{Pru}]_{t}$ available in the corresponding crozier (Figure 2). The slope of this equation gave $\nu_{\mathrm{R}}$, which is $v_{\mathrm{A}}$ relative to $[\mathrm{Pru}]_{t}, 0.380 \pm 0.008 \mu \mathrm{g}$ $\mathrm{HCN} \min ^{-1} \mathrm{mg}^{-1}[\mathrm{Pru}]_{t}$ during the first $180 \mathrm{~min}$ after tissue crushing. Based on this strong correlation, which suggests a first-order reaction on $[\mathrm{Pru}]_{t}$, it was possible to examine collectively the whole set of kinetic experiments by normalizing all $\mathrm{HCN} \mathrm{g}^{-1} \mathrm{dw}$ of plant readings against $[\mathrm{Pru}]_{t}$ in each individual crozier.

The time-dependent accumulated formation of $\mathrm{HCN} \mathrm{g}^{-1} \mathrm{dw}$ of crozier and relative to $[\mathrm{Pru}]_{t}$ that emerged (Figure 3) followed a hyperbolic course whose mathematical expression [Eq. (3)] is the normalized rate equation of the HCN evolution in bracken croziers.

$$
\Re\left(\mu \mathrm{g} \mathrm{HCN} \mathrm{g}^{-1} \mathrm{dw} \mathrm{min}^{-1}\right)=\frac{P_{1} t}{P_{2}+t}[\mathrm{Pru}]_{t}
$$

where $t=$ time (min)

$$
\begin{aligned}
& P_{1}=103.2 \pm 2.6 \\
& P_{2}=132.5 \pm 9.7 \\
& \chi^{2}=8.48
\end{aligned}
$$

In order to estimate the initial velocity $v_{i}$ of the overall process, the accumulated formation of $\mathrm{HCN}\left(\mu \mathrm{g} \mathrm{HCN} \mathrm{g}^{-1} \mathrm{dw}\right)$ released during the first $180 \mathrm{~min}$ of individual bracken samples was adjusted mathematically to a $2^{\circ}$ polynome. The 


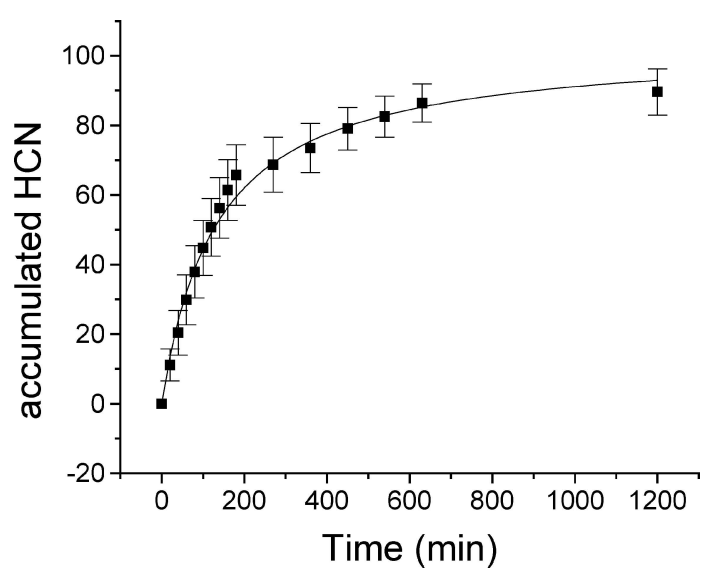

FIG. 3. [Pru $]_{t}$-standardized time-dependent accumulation of $\mathrm{HCN}\left[\mu \mathrm{g} \mathrm{g}^{-1} \mathrm{dw} \mathrm{mg}^{-1}(\mathrm{Pru})_{t}\right]$ produced by young croziers of $P$. arachnoideum until complete decomposition of the contained prunasin. Error bars are one standard deviation of the means $(N=34)$.

first degree coefficient, representing the slope at the onset of the data, gave $v_{i}$. It varied widely from 2.29 to $47.86 \mu \mathrm{g} \mathrm{HCN} \mathrm{g}^{-1} \mathrm{dw} \mathrm{min}^{-1}$, but it was also consistently positively associated with $[\mathrm{Pru}]_{t}$ in each sample (data not shown) $v_{i}=$ $2.78( \pm 1.75)+0.14( \pm 0.02) \times[\text { Pru }]_{t} \mathrm{~g}^{-1} \mathrm{dw} ; r=0.812 ; \mathrm{SD}=5.13 ; P<$ $0.001)$.

Cyanide Evolution and Enzyme Activity. As the decomposition of prunasin not only depends on [Pru $]_{t}$ but also on $\beta$-glucosidase activity, there was the need to prove whether enzyme activity is tied to or is independent from $[\mathrm{Pru}]_{t}$ in $P$. arachnoideum. To this end, the initial velocities of a set of 12 crozier samples were explored under two conditions: first, the kinetics of the accumulation of evolved HCN was monitored during the first $180 \mathrm{~min}$, while $[\mathrm{Pru}]_{t}$ was determined after $1200 \mathrm{~min}$. To a second set of the same samples, enough purified prunasin was added to reach $12 \mathrm{mg} \mathrm{g}^{-1} \mathrm{dw}$ and the kinetics was again determined. After 180 $\min , 57.24 \pm 9.88 \%$ of $[\mathrm{Pru}]_{t}$ had decomposed in the first set, whereas $49.86 \pm$ $6.30 \%$ decomposed in the $[\mathrm{Pru}]_{t}$ normalized group. Both figures were undifferentiated (ANOVA $F=3.36, P=0.062$ ), although the range of $v_{i}$ was visibly narrowed by normalization of the prunasin content in the set of croziers studied (Figure 4).

In relation to the kinetics of prunasin decomposition in the presence of additional $\beta$-glucosidase, the initial velocities of $\mathrm{HCN}$ evolution with and without added enzyme were $45.36 \pm 4.42$ and $47.86 \pm 3.52 \mu \mathrm{g} \mathrm{HCN} \mathrm{min}^{-1} \mathrm{~g}^{-1}$, respectively. After $100 \mathrm{~min}$, the proportion of decomposed prunasin relative to [Pru $]_{t}$ was 0.242 and 0.250 with and without, added enzyme, respectively. 


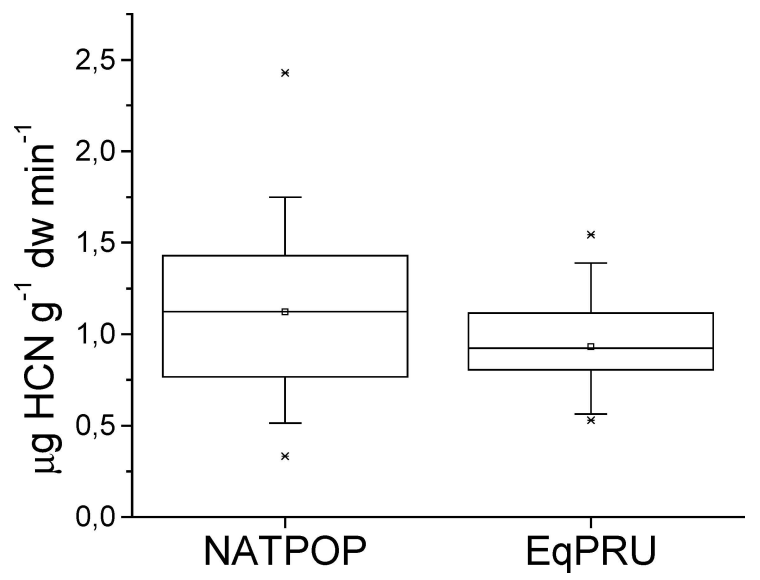

FIG. 4. Comparison of initial rates of $\mathrm{HCN}$ evolution $\left(\mu \mathrm{g} \mathrm{HCN} \mathrm{g} \mathrm{gw} \mathrm{min}^{-1}\right)$ of a natural population (NATPOP) of $P$. arachnoideum croziers and the same samples whose prunasin content was corrected to $12.0 \mathrm{mg} \mathrm{g}^{-1} \mathrm{dw}$ (EqPRU) by the addition of purified prunasin. The square symbol within the boxes denotes the means of the data, the horizontal lines in the box indicate the 25th, 50th, and 75th percentile values. Error bars denote 5th and 95th percentile values.

\section{DISCUSSION}

Tropical plants appear to be more stressed by invertebrate herbivory than those from temperate climates, due to greater insect species diversity and their year round presence. The ensuing pressure finds a response, for example, in the frequency of cyanogenesis (Thomsen and Brimer, 1997). Croziers of P. arachnoideum in the northern Andes appear to respond to this general pattern by their sole prunasin content, which collectively taken display a continuous trend (Figure 1A), and the elevated frequency of the cyanogenic genotype. Under the environmental constraints of these habitats, most of the population within the sampling universe of this study $(>70 \%)$ synthesize and store $15-40 \mathrm{mg} \mathrm{g}^{-1} \mathrm{dw}$ of prunasin, and some individual croziers contain in excess of $100 \mathrm{mg} \mathrm{g}^{-1} \mathrm{dw}$ (Figure 1B). Upon complete conversion, this prunasin will turn into $1370-3660 \mu \mathrm{g} \mathrm{HCN} \mathrm{g}^{-1} \mathrm{dw}$ and occasionally up to $9150 \mu \mathrm{g} \mathrm{g}^{-1} \mathrm{dw}$. This quantity surpasses that found in some strongly cyanogenic strains of Lotus corniculatus such as the Aran variety from Ireland that can yield $2205 \mu \mathrm{g} \mathrm{HCN} \mathrm{g} \mathrm{dm}^{-1}$ and is selected against by voles (Viette et al., 2000). Within the sample range of $[\mathrm{Pru}]_{\mathrm{t}}$ found in $P$. arachnoideum, four populations (Table 1) that represented well the prunasin content of the majority of plants in the area were selected for the kinetic studies.

Prunasin content is insufficient to postulate a comprehensive cyanide-based defense in bracken. When the natural prunasin-HCN conversion rate is considered, 
two defense strategies emerge. First, if the rate of conversion is sufficiently fast, the $\mathrm{HCN}$ evolved should have a deterrent effect on the plant predator as it feeds on its tissues and protection should take place in the brief feeding time span. As a result, damage to affected plant parts may be limited. Secondly, if the rate of HCN formation is much slower than the rate at which the plant tissue is devoured, little $\mathrm{HCN}$ will be available for immediate deterrence and a large proportion of prunasin will enter the gut of the predator and continue its decomposition in the digestive tract. Confined to the lumen, the HCN released would be bound to cause the greatest harm. This will depend on the size, eating strategy of the predator, amount of plant eaten, and the intervention of metabolic processes of detoxification such as the rhodanese sulfur transfer and the $\beta$-cyanoalanine pathway (Beesley et al., 1985). Inhibition of plant $\beta$-glucosidase activity by the herbivore mouth secretions is also conceivable. The frond itself would suffer the greatest damage, but the loss of fitness or even death of the predator-as it occurs in farm animals exposed to cyanogenic pastures-will eventually be to the advantage of the remaining plant fronds.

At the temperature profiles of the tropical mountains where bracken thrives, the conversion of prunasin into $\mathrm{HCN}$ in $P$. arachnoideum occurs relatively fast, as indicated by the average initial velocity of $0.418( \pm 0.014) \mu \mathrm{g} \mathrm{HCN} \mathrm{min}{ }^{-1} \mathrm{mg}^{-1}$ $[\mathrm{Pru}]_{\mathrm{t}}$ which converts to a mean absolute velocity of $6.722 \mu \mathrm{g} \mathrm{HCN} \mathrm{min}{ }^{-1} \mathrm{~g}^{-1}$ $\mathrm{dw}$ of plant. When compared with the only available data (Goodger et al., 2002) for $E$. polyanthemos foliage for which the initial velocity was calculated as 0.02 to $0.14 \mu \mathrm{g} \mathrm{HCN} \mathrm{h}^{-1} \mathrm{~g}^{-1} \mathrm{dw}$, meaning $0.33-2.3 \times 10^{-3} \mu \mathrm{g} \mathrm{HCN} \mathrm{min}^{-1} \mathrm{~g}^{-1} \mathrm{dw}$, it is apparent that $P$. aquilinum possesses a much more powerful cyanide response to the crushing of its fiddleheads. The standard plot in Figure 3 also gives an estimation of the variation of this velocity as time progresses that it was found to follow a rapidly decaying exponential function very closely represented by equation (4):

$$
\frac{\Delta v_{\mathrm{A}}}{\Delta \tau}=\mathrm{A}[\mathrm{Pru}]_{t} e^{-(t / b)}
$$

where

$$
\begin{aligned}
A & =0.703 \pm 0.024 \\
b & =164.99 \pm 10.11 \\
t & =\text { time }(\min ) \\
\chi^{2} & =7.15 \times 10^{-4}
\end{aligned}
$$

The abrupt decay in the rate of $\mathrm{HCN}$ production indicates that in $P$. arachnoideum the overall decomposition of prunasin into HCN is modulated to yield a flash of defense material soon after injury of plant tissue. The initial rate $v_{i}$ is a function of the activity of reaction components, prunasin, and lytic enzymes in bracken. The significant positive correlation illustrated in Figure 2 suggests 
that the genes encoding for prunasin and $\beta$-glucosidase synthesis, though independent, may be activated in concert. Consistent with this is the conservative percentage of prunasin decomposed after $180 \mathrm{~min}$ that took place in croziers containing a natural quantity of prunasin $(57.24 \pm 9.88 \%)$ and the same croziers with added prunasin to yield the same amount of the cyanogenic glucoside $(49.86 \pm$ $6.30 \%$ ). Namely, in both cases the same proportion of prunasin was broken down. This, in addition to the narrowing of the initial velocities (Figure 4 ) of the 12 samples used for this part of the study, is an indication that within this group of crosiers, $\beta$-glucosidase activity is not rate limiting and possibly exceeds the required activity for effective decomposition of the prunasin contained in these fiddleheads. A concurring result stems from the absence of statistical differentiation in the initial velocities of prunasin decomposition in croziers with and without added $\beta$-glucosidase $\left(45.36 \pm 4.42\right.$ and $\left.47.86 \pm 3.52 \mathrm{mg} \mathrm{HCN} \mathrm{min}^{-1} \mathrm{~g}^{-1} \mathrm{dw}\right)$. Hence, not only an excess of enzyme activity is contained in these crosiers, but also the activity of the enzyme is independent of $[\mathrm{Pru}]_{t}$. A similar conclusion emerged from the work of Goodger et al. (2002) in E. polyanthemos, although other trees of this genus did not show such a correlation (Gleadow and Woodrow, 2000).

The application of Eq. (3) gives a more accurate estimate to these considerations. When the necessary variables are introduced [Eqs. (4) and (5)], it is possible to calculate the amount of $\mathrm{HCN}$ evolved into the atmosphere as a function of time and prunasin concentration while the predator feeds on the bracken fiddleheads, as well as the amount of prunasin that becomes part of its lumen.

$$
\mu \mathrm{g} \mathrm{HCN} \text { evolved }=\left\{\frac{P_{1} \times t}{P_{2}+t}\right\} \times[\mathrm{Pru}]_{t} \times\left\{\frac{27}{295}\right\} \times 10 \times W
$$

and

$$
\mu \mathrm{g} \mathrm{HCN} \mathrm{(equiv)} \mathrm{ingested}=[\mathrm{Pru}]_{t} \times\left\{\frac{27}{295}\right\} \times 10 \times W \times\left\{100-\frac{P_{1} \times t}{P_{2}+t}\right\}
$$

where

$[\mathrm{Pru}]_{t}=$ total prunasin content $\left(\mathrm{mg} \mathrm{g} \mathrm{dm}^{-1}\right)$ in the crozier $W=$ weight of the crozier as dry mass $(\mathrm{g})$

The 27/295 factor is the ratio of HCN-prunasin molecular weights, and " 10 " is the resulting conversion factor of $\mathrm{mg}$ [Pru] into $\mu \mathrm{g} \mathrm{HCN}$ and the 100 to 1 scaling in the plot used (not shown).

Application of these expressions to a chewing insect that, for example, eats $100 \mathrm{mg}$ of fresh crozier head containing $20 \mathrm{mg}$ Pru and $88 \%$ moisture, in $10 \mathrm{~min}$, results in $2.01 \mu \mathrm{g}$ of $\mathrm{HCN}$ and by extension $7.89 \mu \mathrm{g}$ of benzaldehyde being 
released in and around the mouth parts of the predator in this time. In this model, we assume that the equimolar amount of benzaldehyde is produced at the same rate as $\mathrm{HCN}$, since both are products of the same reaction. Although the $\mathrm{LD}_{50}$ of $\mathrm{HCN}$ has been determined for many animal species, it remains to be ascertained whether sufficient $\mathrm{HCN}$ diffuses into the air and is capable of affecting the feeding behavior of insect herbivores. Benzaldehyde is repellent against ants (Myrmica americana) $\left(\mathrm{ED}_{50}=375 \mu \mathrm{g} \mathrm{ml}^{-1}\right)$ in regurgitates of Malacosoma americanum larvae when the caterpillars were fed cyanogenic Prunus leaves (Peterson et al., 1987). If the fraction of this solution taken up by each individual ant is assumed to be $0.5 \mu \mathrm{l}$, $\mathrm{ED}_{50}$ would be $1.87 \mu \mathrm{g}$ of benzaldehyde in Peterson's model. Obviously, this much benzaldehyde would not result from the decomposition of an equivalent amount of crozier tissue (about $0.5 \mathrm{mg}$ ) that an individual ant might conceivably nibble from the crozier. Hence, deterrence by the liberated allelochemicals during insects feeding time is likely to be insufficiently effective, at least against $M$. americana unless HCN and benzaldehyde act as synergists, as linamarin and histamine do in Zygaena butterflies (Muhtasib and Evans, 1987). No information exists on such synergy in prunasin-HCN-benzaldehyde at this time, nor quantitative data on the alteration of insects feeding behavior and toxicity by these materials acting together is available. Equations (4) and (5) also show that the larger the animal and, therefore, the greater the amount consumed together with feeding rate, the greater the amount of HCN (and benzaldehyde) released (Table 2), so a more effective feeding deterrence may result.

Equations (4) and (5) also reveal that after $10 \mathrm{~min}$ of feeding time in our model insect case, less than $10 \%$ of the total $\mathrm{HCN}$ potential will have been released. The remaining prunasin, which amounts to $91.7 \%$ of $[\mathrm{Pru}]_{t}$ will be transferred into the gut, representing a toxic potential of $22.17 \mu \mathrm{g} \mathrm{HCN}$ if it all

TABle 2. Amounts of HCN $(\mu \mathrm{g})$ ReleAsed to the Air AND InSIDE the HERBIVORE GUT AS A FUNCTION OF QUANTITY OF P. arachnoideum Croziers Devoured and Time used IN FEEding ON THESE

\begin{tabular}{|c|c|c|c|c|c|c|}
\hline \multirow[b]{3}{*}{ Time (min) } & \multicolumn{6}{|c|}{ Amount of crozier eaten $(\mathrm{g})$} \\
\hline & \multicolumn{2}{|c|}{0.1} & \multicolumn{2}{|c|}{5} & \multicolumn{2}{|c|}{100} \\
\hline & Evolved & Eaten & Evolved & Eaten & Evolved & Eaten \\
\hline 1 & 0.22 & 23.96 & 10.79 & $1,198.2$ & 215.5 & $23,963.4$ \\
\hline 5 & 1.05 & 23.13 & 52.27 & $1,156.7$ & $1,045.0$ & $23,133.7$ \\
\hline 10 & 2.01 & 22.17 & 100.65 & $1,108.3$ & $2,013.7$ & $22,166.0$ \\
\hline 50 & 7.76 & 16.42 & 387.88 & 821.1 & $7,757.0$ & $16,421.4$ \\
\hline 100 & 12.06 & 12.12 & 602.97 & 606.0 & $12,059.9$ & $12,119.7$ \\
\hline
\end{tabular}

Note. An average content of $20 \mathrm{mg} \mathrm{g}^{-1} \mathrm{dw}$ of prunasin was assumed. Calculations were performed using Eq. (4) and (5). 
decomposes within the next few hours. This quantity, which amounts to 2217 ppm for a $1 \mathrm{~g}$ insect, and the accompanying $87.03 \mu \mathrm{g}$ of benzaldehyde are bound to cause considerable damage unless the rate of rhodanese, $\beta$-cyanoalanine, or other enzyme based processing of $\mathrm{HCN}$ into innocuous material or the inhibition of prunasin decomposition into $\mathrm{HCN}$ is comparable or faster than the rate of prunasin-HCN conversion according to equation (3). At present, these combined digestive rates remain unknown.

Using a different animal model, sheep might be assumed to consume easily $50 \mathrm{~g}$ of fiddleheads mixed with pastures of the grassland in $5 \mathrm{~min}$, hence evoking the evolution of $522 \mu \mathrm{g} \mathrm{HCN}$ in this time and ingesting enough prunasin to yield $11.6 \mathrm{mg}$ of $\mathrm{HCN}$ in the gut, a potentially hazardous quantity. Adding the benzaldehyde co-product that is formed in an equimolar amount, $2.05 \mathrm{mg}$ will be released into the sheep mouthparts possibly eliciting a sensory aversion reaction to the feed, while $45.5 \mathrm{mg}$ of the aldehyde will be formed in the gut. The higher internal temperature of the herbivore would of course significantly enhance the rate of $\mathrm{HCN}$-benzaldehyde production.

The model figures of Table 2 suggest that the emerging fronds of $P$. arachnoideum possess the potential capacity, in terms of $[\mathrm{Pru}]_{t}$ and rate of $\mathrm{HCN}$ formation at temperatures commonly found in tropical bracken thickets, to embrace the two defense strategies postulated above, causing immediate feeding aversion in some herbivores, and preserving enough latent toxicity in its phytoanticipin form-prunasin - to cause damage inside the attacking organism. However, the balance of both defense routes in the overall HCN-based defense of bracken will depend strongly on the feeding rate, amount ingested by the specific herbivore, and its digestive detoxification reactions, thus opening opportunities to herbivore specialization.

Acknowledgments-The authors are grateful to Consejo de Investigaciones Científicas, Tecnológicas y Humanísticas of Universidad de Los Andes (CDCHT), and to the GQE-ADG Fund for providing financial support for this investigation. The taxonomic evaluation of Dr. John Thomson of the Sydney Botanical Gardens in Sydney, Australia is also gratefully acknowledged.

\section{REFERENCES}

Alonso-Amelot, M. E. 2002. The chemistry and toxicology of bioactive compounds in Bracken Fern (Pteridium ssp.) with special reference to chemical ecology and carcinogenesis, pp. 685740, in Atta-Uhr-Rahman (ed.). Studies in Natural Product Chemistry. Vol. 26, Elsevier Science, Amsterdam.

Alonso-Amelot, M. E. and Oliveros, A. 2000. A method for the practical quantification of cyanogenesis in plant material. Phytochem. Anal. 11:309-316.

Alonso-Amelot, M. E. and Rodulfo, S. 1996.Comparative spatial distribution, size, biomass, and growth rate of two varieties of bracken fern (Pteridium aquilinum L. Kuhn) in a neotropical montane habitat. Vegetatio (Plant Ecol.) 125:137-147. 
Bauer, M., Griengl, H., and SteIneR, W. 1999. Kinetic studies on the enzyme (S)-hydroxynitrile lyase from Hevea brasiliensis using initial rate methods and progress curve analysis. Biotechnol. Bioeng. 62:20-29.

Beesley, S. G., Compton, S. G., and Jones, D. A. 1985. Rhodanese in insects. J. Chem. Ecol. 11:45-50.

Berti, G. and BotTARi, F. 1968. Constituents of ferns. Prog. Phytochem. 1:589-685.

Brimer, L., Christensen, S. B., Molgahrd, P., and Nartey, R. 1983. Determination of cyanogenic compounds by thin-layer chromatography. A densitometric method for quantification of cyanogenic glycosides, employing enzyme preparations ( $\beta$-glucosidase) from helix pomatia and picrate-impregnated ion-exchange sheets. J. Agric. Food Chem. 31:789-793.

BRINKER, A. M. and SEIGLER, D. S. 1992. Determination of cyanide and cyanogenic glucosides from plants, pp. 359-381, in H. F. Linskins and J. F. Jackson (eds.). Plant Toxin Analysis. SpringerVerlag, Berlin.

BUTLER, G. W. 1965. The distribution of the cyanoglucosides linamarin and lotaustralin in higher plants. Phytochemistry 4:127-131.

ConN, E. E. 1979. Cyanide and cyanogenic glycosides, pp. 387-412, in G. A. Rosenthal and D. H. Janzen (eds.). Herbivores, Their Interaction with Secondary Plant Metabolites. Academic Press, New York.

ConN, E. E. 1981. Cyanogenic glycosides, pp. 479-500, in E. E. Conn (ed.). The Biochemistry of Plants. Vol. 7. Academic Press, New York.

COOPER-Driver, G. A., FINCH, S., SwAIN T., and BERNAYS, E. A. 1977. Seasonal variation in secondary plant compounds in relation to the palatability of Pteridium aquilinum. Biochem. Syst. Ecol. 5:177-183.

Ellis, W. M., KeYMER, R. J., and Jones, D. A. 1977. The defensive function of cyanogenesis in natural populations. Experientia 33:309-311.

GEBREHIWOT, L. and BEUSELINCK, P. R. 2001. Seasonal variations in hydrogen cyanide concentration of three lotus species. Agric. J. 93:603-608.

GLEADOW, R. M. and WoODROW, I. E. 2000. Temporal and spatial variation in cyanogenic glycosides in Eucalyptus cladocalyx. Tree Physiol. 20:591-598.

GLEADOW, R. M. and WoODROW, I. E. 2002. Constraints on effectiveness of cyanogenic glycosides in herbivore defense. J. Chem. Ecol. 28:1301-1313.

Goodger, J. Q. D., CAPON, R. J., and WoOdRow, I. E. (2002). Cyanogenic polymorphism in Eucalyptus polyanthemos Schauer subsp. vestita L. Johnson and K. Hill (Myrtaceae). Biochem. Syst. Ecol. 30:617-630.

HADFIELD, P. R. and DYER, A. F. 1986. Polymorphism of cyanogenesis in British populations of bracken (Pteridium aquilinum L. Kuhn), pp. 293-300, in R. T. Smith and J. A. Taylor (eds.). Bracken: Ecology, Land Use and Control Technology. Parthenon Press, Carnforth.

HRUSKA, A. J. 1988. Cyanogenic glucosides as defense compounds. A review of the evidence. J. Chem. Ecol. 14:2213-2217.

JONES, C. G. 1983. Phytochemical variation, colonization and insect communities: The case of bracken ferns (Pteridium aquilinum), pp. 513-558, in R. F. Denno and M. S. McClure (eds.). Variable Plants and Herbivores in Natural and Managed Systems. Academic Press, New York \& London.

JONES, D. A. 1973. Coevolution and cyanogenesis, pp. 213-242, in V. H. Heywood (ed.). Taxonomy and Ecology. Academic Press, London.

JONES, D. A. 1998. Why are so many food plants cyanogenic? Phytochemistry 47:155-162.

JONES, D. A., KEYMER, R. J., and ElLIS, W. M. 1978. Cyanogenesis in plant and animal feeding, pp. 2134, in J. B. Harborne (ed.). Biochemical Aspects in Plant and Animal Evolution. Academic Press, London.

JORNS, M. S. 1980. Studies on the kinetics of cyanohydrin synthesis and cleavage by the flavoenzyme oxynitrilase. Biochem. Biophys. Acta 613:203-209. 
KofoD, H. and EYJOLfsSON, R. 1966. The isolation of the cyanogenic glycoside prunasin from Pteridium aquilinum. Tetrahedron Lett. 12:1289-1291.

LAWTON, J. H. 1976. The structure of the arthropod community on bracken. Bot. J. Linn. Soc. 73:187216.

Low, V. H. K. and Thomson, J. A. 1990. Cyanogenesis in Australian bracken (Pteridium esculentum): Distribution of cyanogenic phenotypes and factors influencing activity of the cyanogenic glucosidase, pp. 105-111, in J. A. Thomson and R. T. Smith (eds.). Bracken Biology and Management. Australian Institute of Agricultural Science AIAS Occasional Publication No. 40. Wahroonga, New South Wales, Australia.

Magalhaes, C. P., XAVIER, J., and CAMPOS, A. P. 2000. Biochemical basis of the toxicity of manipueira (liquid extract of cassava roots) to nematodes and insects. Phytochem. Anal. 11:57-60.

MuHTASIB, B. and Evans, D. L. 1987. Linamarin and histamine in the defense of adult Zygaena filipendulae. J. Chem. Ecol. 13(1):133-142.

NAHRSTEDT, A. 1985. Cyanogenesis and the role of cyanogenic compounds in insects. Plant Syst. Evol. 150:35-47.

NAHRSTEDT, A. 1988. Cyanogenic compounds as protecting agents for organisms, pp. 131-150, in D. Evered and S. Harnett (eds.). Cyanide Compounds in Biology. John Wiley \& Sons, Chichester, United Kingdom.

ORTEGA, F. J. 1990. El género Pteridium en Venezuela: Taxonomía y distribución geográfica. Biollania 7:47-56.

Peterson, S. C., Johnson, N. D., and Leguyader, J. L. 1987. Defensive regurgitation of allelochemicals derived from host cyanogenesis by eastern tent caterpillars. Ecology 68:1268-1272.

SALINAS, P. J. and ORTEGA S. J. 1990. Comunidades de artrópodos en la maleza Pteridium aquilinum (L.) Kuhn en los Andes Venezolanos y primer hallazgo de Acyrthosiphon cyatheae Holman (homoptera:aphididae) en Suramérica. Turrialba 40:168-171.

SCHAPPERT, P. J. and SHORE, J. S. 1999a. Cyanogenesis, herbivory, and plant defense in Turnera ulmifolia on Jamaica. Ecoscience 6:511-520.

SCHREINER, I., NAFUS, D., and PIMENTEL, D. 1984. Effects of cyanogenesis in bracken fern (Pteridium auqilinum) on associated insects. Ecol. Entomol. 9:69-70.

SEIGLER, D. S., 1998. Cyanogenic glycosides and cyanolipids, pp. 273-296, in D. S. Seigler (ed.). Plant Secondary Metabolism. Kluwer Academic Press, Boston.

THOMSEN, K. and BRIMER, L. 1997. Cyanogenic constituents in woody plants in natural lowland rainforest in Costa Rica. Bot. J. Linn. Soc. 124:273-294.

VetTER, J. 2000. Plant cyanogenic glycosides. Toxicon 38:11-36.

VietTe, M., TetTAmanti, C., and SAucy, F. 2000. Preference for acyanogenic white clover (Trifolium repens) in the vole Arvicola terrestris. II. Generalization and further investigations. J. Chem. Ecol. 26:101-122.

Zagrobelny, M., BaK, S., Rasmussen, A. V., Jørgensen, B., Naumann, C. M., and Møller, B. L. (2004). Cyanogenic glycosides and plant-insect interactions. Phytochemistry 65:293-306. 